\title{
A Module of Silverware In Sentral Amai Setia Koto Gadang
}

\author{
M. Nasrul Kamal \\ State University of Padang
}

\begin{abstract}
Due to fulfill the needs of silversmiths Sentral Amai Setia Koto Gadang, the researcher made a module of silverware in Sentral Amai Setia Koto Gadang. This research was Research and Development which did to help the silversmiths design the silverware of Koto Gadang. The module was developed by applying 4-D model 1) define; 2) design; 3) develop; and 4) dessiminate. The interview, observation, and documentation were used as instruments and the data reduction, data display, and data conclusion were done on analyzing the data. The module was tested and concluded that it was very valid $96 \%$, very practical $93,3 \%$ and effective based on ttest analysis that $t_{\text {count }}$ is greater than $t_{\text {table }}(3,960>1,833)$. It can be concluded that the module has an effect on increasing the knowledge of silversmiths in Sentral Amai Setia Koto Gadang.
\end{abstract}

Keywords: Module, Silversmiths, Silverware, Sentral Amai Setia Koto Gadang

\section{INTRODUCTION}

This study originated from the empirical findings that "the silverware in Sentral Amai Setia Koto Gadang nowadays not considered from the quality material as decorative purposes but rather to the design" (interviews with Leo on Sunday, April $\left.6^{\text {th }}, 2014\right)$. This causes a woman does not wear jewelry of silver because of the purity of silver, but tend to a trend that demands silversmiths to produce the products in accordance with the present trend. If examined back, silverware in Sentral Amai Setia Koto Gadang is one piece of art that had been developed long time ago, where according to Leo in the past "this craft is intended as a scientific equipment ceremonial and equipment for the needs of Penghulu (Progenitor)".

In 1911, according to Djaja (1980) "the forms of silverware Sentral Amai Setia Koto Gadang emphasis on usability functions with decorative motives containing symbolic value, as well as aesthetic value". Haluan (Wednesday, May $23^{\text {rd }}, 2012$ ) mentions that "some kind of silverware products in the past intended as supplies ceremonies". According to Djaja (1980) in 1911 "various kinds of craft products such hairpin, ring, earring, Keris and so are the objects of high social value, because it is for the prince or the Datuk". Thus the presence of objects of silver in the past made as devotion, both for spiritual and social interests.

Art craft was born of the demands of the human need to help daily activities in accordance with the dynamics of culture and the development of human thought. The art craft also called kriya is a craft that has the value of beauty, then evolved into objects for creativity. Padang Ekspres (Sunday, February $1^{\text {st }}, 2009$ ) revealed that the art craft "was created to meet the basic needs of human life, hence the craft has a practical function and aesthetic function". This is why silverware Sentral Amai Setia Koto Gadang is not considered from the quality material as decorative purposes but rather to the design. This means that the changes of silverware Sentral Amai Setia Koto Gadang undergoes a transformation, both in terms of motive, form, function and meaning.

In terms of motive, the design of silverware is grown today are processed and elaborated with elements of modern art which influenced by foreign, then the silverware Sentral Amai Setia Koto Gadang more creative and innovative so that it can compete in the global market. While the motive used constantly bakarang motive that has been passed down as a characteristic silver motive Sentral Amai Setia Koto Gadang. Kamil (2007) revealed that "the current function of the silver Sentral Amai Setia Koto Gadang has undergone a shift in the function of the sacred to the profane, practical functions, aesthetically, socially, and economically, which is capable of prospering society Koto Gadang, as well as the contained meaning".

In terms of form, according to Leo (the interview on Sunday, April $6^{\text {th }}, 2014$ ) the silver design developed at this time is "influenced by the demands of consumers both inside and outside the country". It affects the silversmith of Sentral Amai Setia Koto Gadang in making the design using geometric decorative motives, plants, and local nuances of Minang.

In terms of function, according to Leo (the interview on Sunday, April $6^{\text {th }}, 2014$ ) the silver design developed at this time is "as accessories for women and men in line with the development of tourism in West Sumatera". Chaprian (2013) revealed that "this condition is used by silversmiths Sentral Amai Setia Koto Gadang to start producing silver with a design that is practical, aesthetic, profane, social, economical, which can meet the needs of local and foreign consumers".

In terms of significance, according to Leo (the interview on Sunday, April $6^{\text {th }}, 2014$ ) the silver design which is currently developed as "symbol for its people". The object contains the meaning of the rules and norms

DOI: 10.9790/0837-2108083945 $\quad$ www.iosrjournals.org $39 \mid$ Page


relating to the way of life of a community. Then the meaning of symbols can provide information about the philosophy of life, cultural order, in this case the cultural property could be said to be a symbol for its users when associated with the function of objects in people's lives.

As the silversmiths Sentral Amai Setia Koto Gadang it is given a limited movement because in the process no external considerations that must be taken into account. If the silversmiths is moving too far ahead of public understanding, then the result will disappoint the design and consumers will stop to consume. Then in the concept design material, according to Sachari (1986) there is a "line, plane, space, color, spot, and shapes which in principle is currently on the standpoint of the design concept of silver in Koto Gadang".

Today the silverware Sentral Amai Setia Koto Gadang tend to be the trend and used as disposable items or accessories. This is a real cultural transformation that occurs at any time even sometimes difficult to predict. Something interesting to note from the above problems is the useful of cultural change of silverware Sentral Amai Setia Koto Gadang with all the positive and negative impacts. Therefore, it is necessary to examine the transformation of form design silverware at Sentral Amai Setia Koto Gadang.

Based on the transformation of form design of silverware in Sentral Amai Setia Koto Gadang it is important for the researcher to develop a model of transformation of silverware Koto Gadang in Sentral Amai Setia. Besides, the development of module is based on the fact that silverware is learned by silversmiths untouched local content. Another thing that the current silverware Koto Gadang is very rare, so its presence increasingly known yet, and it is unfortunate, according to Leo (Sunday, April $6^{\text {th }}, 2014$ ) that "the number of traditional silversmiths in Koto Gadang are currently very fewer increasingly feared even disappear".

This statement was also confirmed by observations and interviews obtained from the leader Sentral Amai Setia Koto Gadang which states that "the silversmith's currently very fewer and almost disappeared". For now only silversmith Koto Gadang only fathers with middle age who only have the ability (expert) of silver, as well as making miniature (accessories). While the silver skill Koto Gadang there are several work processes to produce silver Koto Gadang like menarek silver, assemble, design motives, and decorate objects. From work processes that have been mentioned, designing and decorating motive of ring, bracelet and a miniature showing the principal characteristic of the silver in Sentral Amai Setia Koto Gadang.

Based on the problems mentioned above, there is concern over time, silverware in Sentral Amai Setia Koto Gadang can not be passed to the younger generation. It was deemed important to develop a module of silverware in Sentral Amai Setia Koto Gadang.

\section{MATERIALS AND METHODS}

This research used Research and Development. Research and Development according to Nana (2008) is "a process or steps to develop a new product or an existing accountable". The products such learning materials like books, module, or a computer program. Research and Development in this research aims to develop a module of silverware in Sentral Amai Setia Koto Gadang to help artisans designing silver Koto Gadang. The development of this module used 4-D models such stated by Thiagarajan et al in Trianto (2010). The models consist of 1) define; 2) design; 3) develop; and 4) dessiminate.

The instruments used in this study were interviews, observation and documentation. Analysis of the data in this study follows the concept of qualitative data analysis Miles and Huberman (1992), the data analysis is "interactive and runs continuously until complete, so the data is saturated. Activities in the analysis of the data were data reduction, data display, and conclusion".

\section{RESULTS AND DISCUSSION}

\section{Define Phase}

At this stage, the researcher did need analysis as an early stage of developing a module of silverware Sentral Amai Setia Koto Gadang. The need analysis was conducted to obtain important information for developing products in the form of a module a module of silverware Sentral Amai Setia Koto Gadang. The results of the needs analysis concluded that the silversmiths want to be taught about design the ring of men and women.

Then the researcher also analyzed the ability and background of silversmiths. The purpose of this analysis was done to identify the skills, background experiences, attitudes towards learning of silverware and activities that are often carried out by silversmiths. In this study, the purpose of silversmiths analysis is to facilitate instructor in the learning process and appropriae the learning outcomes to the silversmiths. The analysis aims to determine the condition of silversmiths characteristics. The results of the analysis concluded that the silversmiths has owned capabilities in designing necklaces and bracelets but weak in designing the ring.

Then, from the interview obtained it can be described that motivation of silversmiths on the last the learning of silverware did not motivate silversmiths. It tend to wait the demonstration from the instructor in advance, it could be due to the lack of interest on teaching materials and no teaching materials which could lead the silversmiths to self-learning. 
The researcher then analyzed the background of silversmiths that mostly from local silversmiths Koto Gadang. therefore, this module was developed according to the learning environment of silversmiths and it felt no difficulty in studying this module. It added that silversmiths like the variety of colors, therefore the module was developed which has many colors and also display a bit of animation that can provide attraction for crafters.

Based on the analysis of the silversmiths mentioned above, this module was developed in accordance with the conditions and characteristics of the silversmiths. So, during the execution of the learning process is not found the significant constraint, then it occurs an interaction of multi directions from silversmiths to silversmiths and from silversmiths to the instructor.

\section{Design Phase}

Based on the analysis at this stage, then the researcher designed the module of silverware Koto Gadang according to the conditions, needs and characteristics of the silversmiths. Module of silverware Koto Gadang is developed for the instructor to deliver the learning materials of silverware Koto Gadang.

At the design stage, the activities carried out by researcher is preparing outline by composing 1) an introduction that contains a background of developing a module of silverware Sentral Amai Setia Koto Gadang, learning concept of silverware which formulates the notion of learning silverware, the goal of the learning silverware, the significance of learning silverware, the characteristics of silverware, and the signs of learning implementation of silverware; 2) the scheme of a module development of silveware Sentral Amai Setia Koto Gadang includes the preparation phase and the implementation phase; 3) the steps of developing a module silverware Sentral Amai Setia Koto Gadang covering materials to be combined; learning the basic competence and indicator of material activities; selecting and defining the theme of learning; linking basic competence with the material; preparing training syllabus of silverware Koto Gadang; and developing the training implementation silverware Koto Gadang; 4) the material activities include all the materials on the module of silverware Koto Gadang; 5) module implementation plan of silverware Koto Gadang with systematics; and 6) the learning materials related to the theme, and closing.

Table. The Design of Developing A Module of Silverware

\begin{tabular}{|l|l|l|}
\hline No & The Components of Writing & Content \\
\hline 1. & Introduction & $\begin{array}{l}\text { Backgound of the importance a module of silverware } \\
\text { Sentral Amai Setia Koto Gadang }\end{array}$ \\
\hline 2. & $\begin{array}{l}\text { The Scheme of a Module } \\
\text { Development }\end{array}$ & Preparation and Implementation Steps. \\
\hline 3. & The Steps of Developing a Module & $\begin{array}{l}\text { Determining materials to be combined; learning the } \\
\text { basic competence and indicator of material activities; } \\
\text { selecting and defining the theme of learning; linking } \\
\text { basic competence with the material; preparing training } \\
\text { syllabus of silverware Koto Gadang; and developing } \\
\text { the training implementation silverware Koto Gadang; }\end{array}$ \\
\hline 4. & The Material Activities & $\begin{array}{l}\text { The material activities include all the materials on the } \\
\text { module of silverware Koto Gadang }\end{array}$ \\
\hline 5. & Module Implementation Plan & $\begin{array}{l}\text { Module implementation plan of silverware Koto } \\
\text { Gadang with systematics }\end{array}$ \\
\hline 6. & The Learning Materials & The learning materials related to the theme \\
\hline 7. & Closing & Closing the Module \\
\hline
\end{tabular}

At the design stage the researcher carried a module of silverware Sentral Amai Setia Koto Gadang according to the potential in the area. At this stage the module was produced appropriate with the regional potential that have been designed, manufactured, validated and has also been tested. The components of the module consist of 1) cover; 2) chart of module; 3) direction; 4) introduction; 5) table of contents; 6) glossarium; 7) learning activity sheet; 8) test sheet/ evaluation; 9) key answer; 10) feedback; and 11) references.

\section{Develop Stage}

The development phase aims to produce a modul of silverware Koto Gadang, then it is significant to be used in the learning process. The development phase consists of three stages are validation of the product; test the practicalities; and test the effectiveness. The validity test is an activity to validate module by experts and practitioners to declare valid. The validation is performed twice and the revision too to declare it is valid. While the practical and effectiveness were done to see practical or not, as well as the effectiveness of the modules developed. 
Validity test is done by involving the experts were 1) Dr. Buduwirman, M.Pd; 2) Dr. Darmansyah, M.Pd; and 3) Dr. Yasnur Asri, M.Pd. The validity test results conducted on a module of silverware Sentral Amai Setia Koto Gadang concluded that

$$
\begin{aligned}
& \text { Dr. Budiwirman, M. Pd }=\frac{88}{90} \times 100 \%=97,7 \% \text { (A) } \\
& \text { Dr.Yanur Asri, M.Pd }=\frac{89}{90} \times 100 \%=98,7 \% \text { (A) } \\
& \text { Dr. Darmarsyah, M. Pd }=\frac{91}{90} \times 100 \%=99,8 \% \text { (A) } \\
& \text { Total }=\frac{97,7 \%+98,7 \%+99,8 \%}{3}=96 \% \quad \text { (Very valid) }
\end{aligned}
$$

The practical test was conducted through face to face on learning the silverware Sentral Amai Setia Koto Gadang by using observation. The test results concluded that the practical average $\frac{84}{90}$ X $100 \%=93,3 \% \quad($ very practical)

The effective test conducted by t-test analysis. The results of t-test analysis concluded that $t_{\text {count }}$ on this module is greater than $t_{\text {table }}(3,960>1,833)$ and the Sig. $(, 000)<\alpha(0.05)$. From the results it can be concluded that the module has an effect on increasing the knowledge of silversmiths in Sentral Amai Setia Koto Gadang.

\section{Disseminate Phase}

At this stage the researcher deployed the products were developed in order to be used by the wider community. The core activities of this phase is to disseminate the results of product development to the silversmiths in Koto Gadang. Dissemination of product in this module done in Bukittinggi, Payakumbuh, Padang Panjang and Lubuk Basung. According to Boni, one of the silversmiths Koto Gadang in silver work Syafa, ring design that was created had a touch of classic images, and it does not miss the model. Here are the results of design verbal and visual design with a classical style, mixed style and minimalist style.
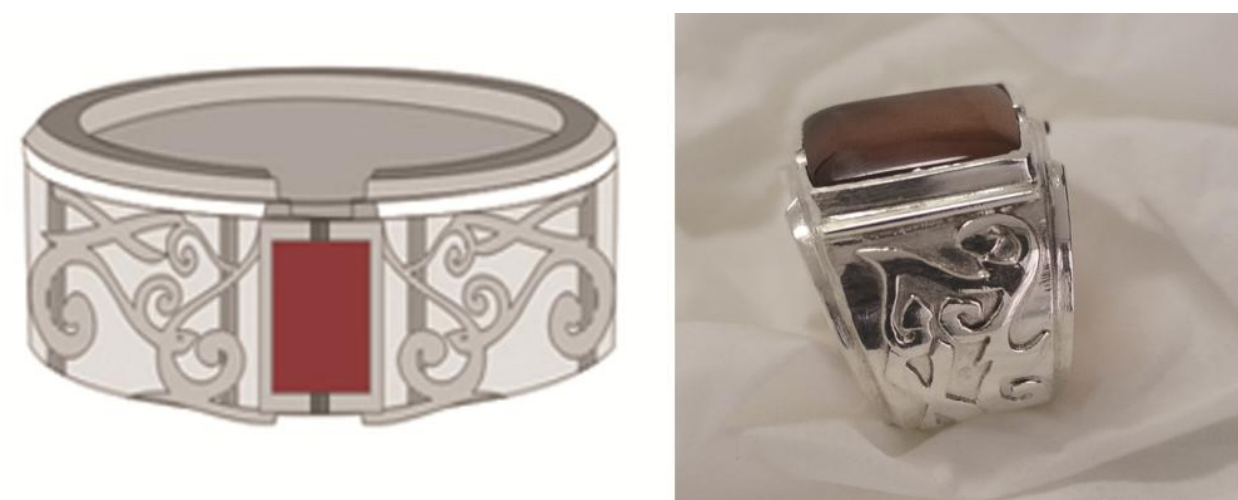

Figure 1. The Final Design and The Result Design with a Classical Style
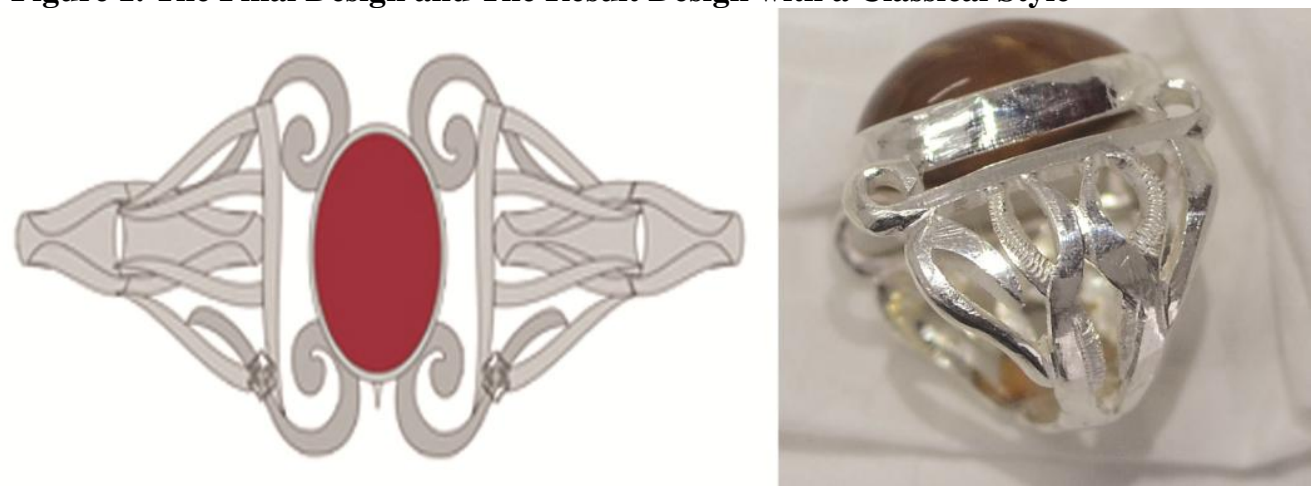

Figure 2. The Final Design and The Result Design with a Classical Style 

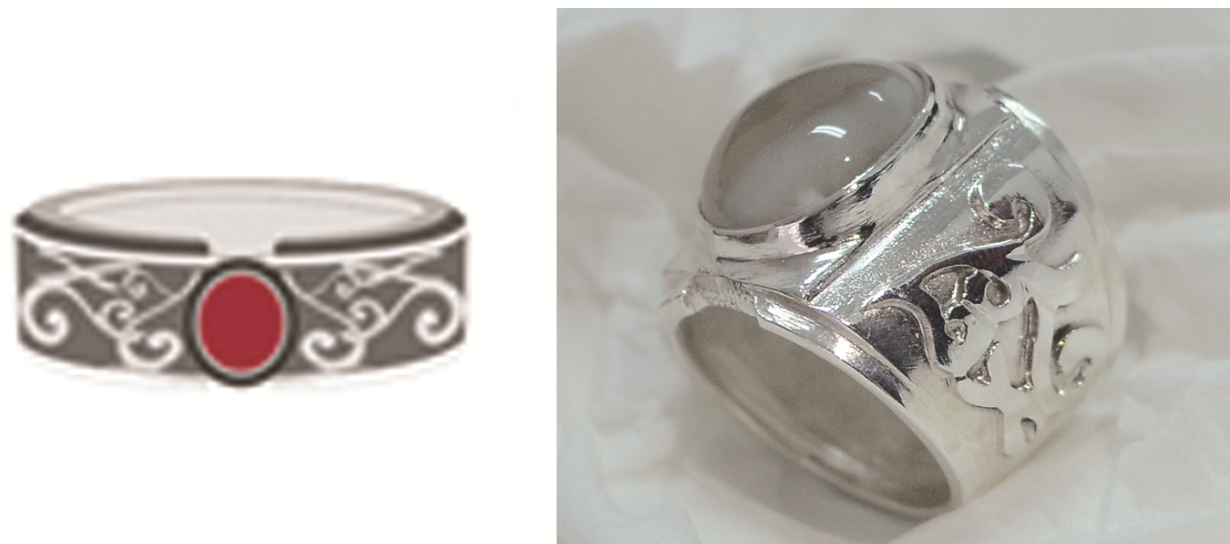

Figure 3. The Final Design and The Result Design with a Classical Style
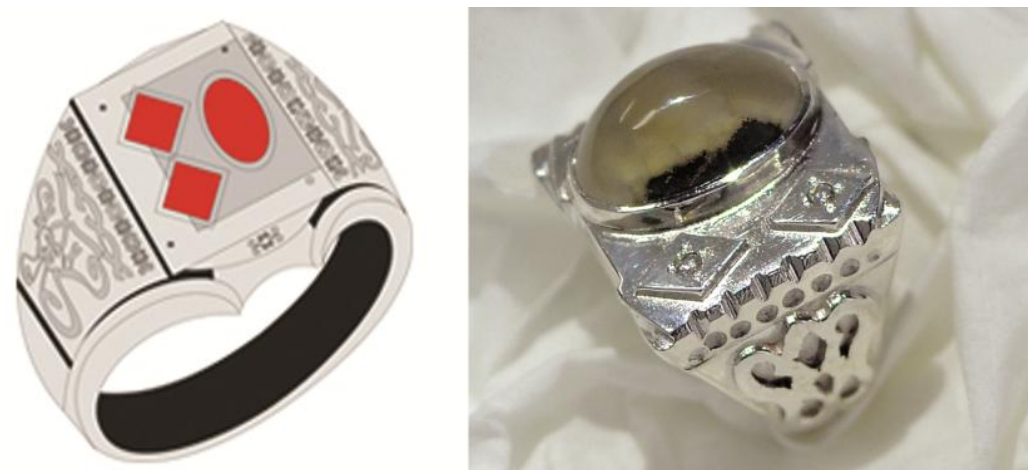

Figure 4. The Final Design and The Result Design with a Mixed Style
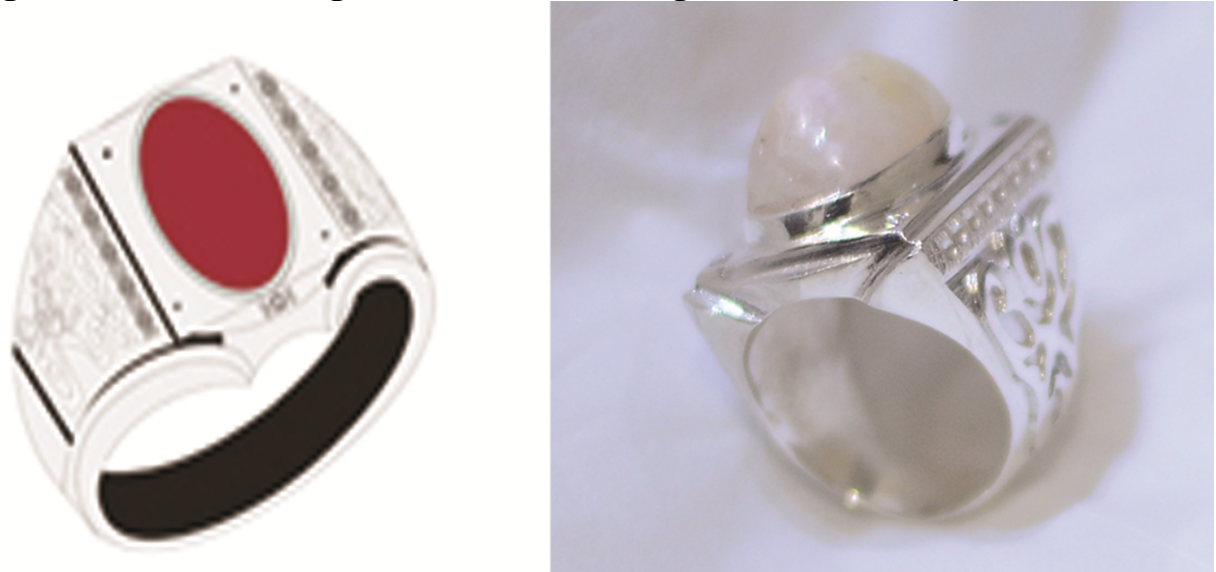

Figure 5. The Final Design and The Result Design with a Mixed Style
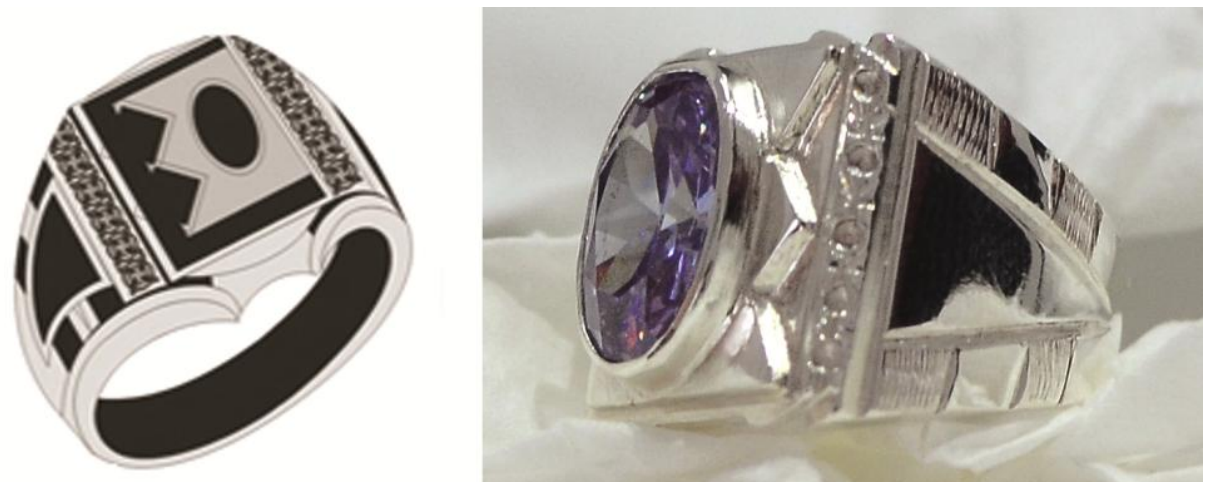

Figure 6. The Final Design and The Result Design with a Minimalist Style 

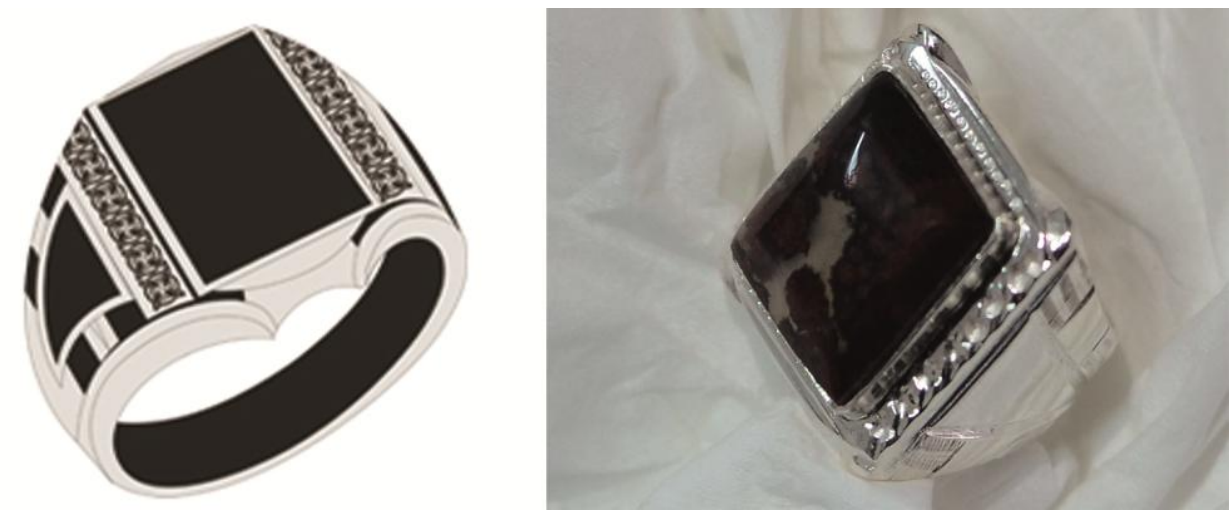

Figure 7. The Final Design and The Result Design with a Minimalist Style

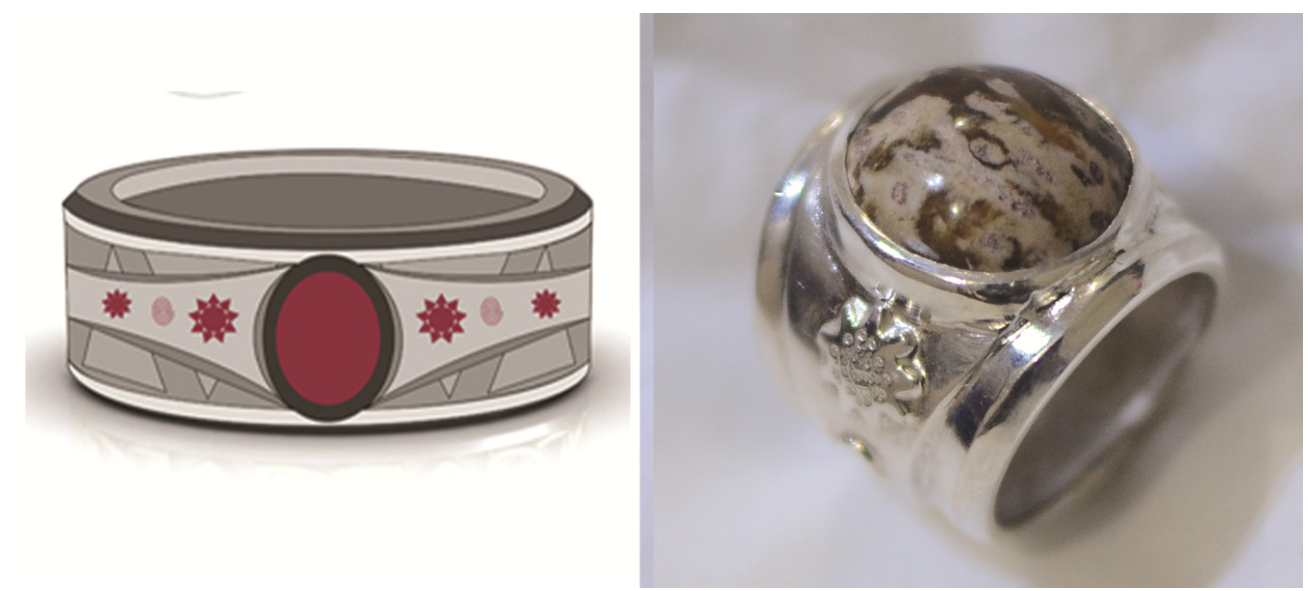

Figure 8. The Final Design and The Result Design with a Minimalist Style

The findings in this study was supported by the findings of Ariusmedi (2003), which concluded that "the symbols of the prince's clothes shift to the communication". Then it is supported by the finding of Salfiani (2012) that concluded "there has been a shift in the role of women in weaving and the weaving skills nearly disappeared". Further, it is supported by the finding of Rustam (2001) which concluded the "local content material provide the meaningful support to the core courses in the curriculum structure". The last is supported by the finding of Ananingsih (2006) which concluded "the learning module goes well, the use of the module by learners in good categories and the use of module by teachers in good categories".

\section{CONCLUSION}

A module of silverware in Sentral Amai Setia Koto Gadang was developed according to the needs of silversmiths. Validity test is done by involving the experts, and the validity test results conducted on a module of silverware Sentral Amai Setia Koto Gadang concluded that the module is very valid 96\%. The practical test was conducted through face to face on learning the silverware Sentral Amai Setia Koto Gadang by using observation. The practical test concluded that the module is very practical 93,3\%. The effective test conducted by t-test analysis. The results of t-test analysis concluded that $t_{\text {count }}$ on this module is greater than $t_{\text {table }}(3,960>$ $1,833)$ and the Sig. $(, 000)<\alpha(0.05)$. From the results it can be concluded that the module has an effect on increasing the knowledge of silversmiths in Sentral Amai Setia Koto Gadang.

\section{REFERENCES}

[1] Ananingsih K. (2006). "Upgrading Potency of Local Fruits to Global Market, the Strategy to Compete on Fruits Globalization". Downloaded on May $29^{\text {th }} \quad 2012 \quad$ on http://docs.google.com/viewer?a=v\&q=cahce:2rcSnUYPD04:isjd.pdii.lipi.go.id/admin/jurnal.

[2] Ariusmedi, (2003). "The Language Form of Prince's Clothes Minangkabau, the Discussion on Component, Form and Symbol's Meaning”. Thesis Magister Program Technology Institute of Bandung.

[3] Chaprian, Rusdi. (2013). Director, Web Adminitration and Founding Father Pelangi Holiday Travel Services. Bukittinggi.

[4] Djaja, Tamar. (1980). Roehana Khudus, Srikandi Mr. Jakarta: Mutiara. 
[5] Kamil, Insannul and Hapsari, Indria. (2007). "Developing a Model of Sea Industry Based Cluster in Padang”. Joumal Optimasi Sistem Industri, Vol. 6 No. 2 Mai 2007 Technic Industry Andalas University.

[6] Miles, Mathew B. \& Huberman, A. Michael. (1992). Qualitative Data Analysis. Translater Tjejep Rohendi Rohidi. Jakarta: UI Press.

[7] Nana. (2008). Learning Assessment. Bandung: PT Remaja Rosdakarya.

[8] Rustam, Moctar. (2001). Synopsis Esteti, Second Edition. Jakarta: EGC.

[9] Sachari, Agus. (1986). Design Paradigm of Indonesia. Jakarta: Rajawali.

[10] Salfiani. (2012). "The Shift Role of Woman on Weaving". Thesis Magister Program State University of Padang.

[11] Trianto. (2010). A Model of Integrated Learning, Theory and Practice. Jakarta: Prestasi Pustaka 